\title{
On the Culture of Creativity in Mathematics Education
}

\begin{abstract}
Culture of creativity in mathematics education is grounded in definitions of creativity which underline our research and efforts of its classroom facilitation. However, the statement "there is no single, authoritative perspective or definition of creativity in mathematics education" (Mann, 2006; Sriraman, 2005; Leikin, 2011, Kattou et al., 2011) leaves practitioners without an idenifiable viewpoint in teaching. Therefore culture of creativity in mathematics education doesn't have solid foundations conflating, among other things, a research into creativity with research into giftedness. Prabhu and Czarnocha (2014) have argued at PME 38 for the acceptance of bisociation of Koestler's Act of Creation, that is a spontaneous leap of insight' as the authoritative definition of creativity. The paper presents this bisociation theory of an "Aha!" moment and identifies this moment as one during which mind can focus and eliminate inhibiting habits of mind. The paper explores cultural values brought forth by the new definitions of creativity such as its democratization, the unity of creativity, motivation in learning, and the simultaneity of attention. The examples and methods of classroom facilitation are henceforth presented. The distinction between bisociative and associative thinking shows and introduces the concept of simultaneity of attention as new type of attention in learning (Mason, 2008).
\end{abstract}

Key words: creativity, bisociation, 'Aha moment', simultaneity of attention.

\section{Introduction}

The elementary meaning of the term 'culture is probably about the way people do things. The Oxford English Dictionary looks upon culture as "arts and other manifestations of human intellectual achievement regarded collectively". Thus 'culture' can denote both processes of cultivation as well as their results, the objects of cultivation could encompass such activities as growing plants, customs, arts and, as is of interest to us, results of human intellectual achievements.

Of our primary interest in this paper is the definition of culture of creativity in mathematics education and the efforts in its facilitation in the classroom. We here reflect on the statement (quite possibly accepted within the profession that "there is no single, authoritative perspective or definition of creativity in mathematics education") (Mann, 2006; Sriraman, 2005; Leikin, 2011, Kattou et al., 2011).

1 bczarnocha@hostos.cuny.edu 
The Wallas (1926) definition of creativity based on the Gestalt ${ }^{2}$ theories postulates the following general process of preparation, incubation, illumination and verufication

The second definition measures the products of creativity through Torrance Tests of Creative Thinking (1974). It involves simple tests of divergent thinking and other problem-solving skills, which are scored on:

- Fluency - The total number of interpretable, meaningful and relevant ideas generated in response to the stimulus.

- Originality - The statistical rarity of the responses among the test subjects.

- Elaboration - The amount of detail in the responses.

Leikin (2007) and Silver (1997) transformed creativity to fluency, flexibility and originality making the definition one of the bases for understanding creativity in mathematics education. While the Wallas' definition focuses on the psychological neighborhood of the creative insight, the Torrance definition addresses the quantity and rarity of its products. Neither of these definitions focuses on the creative act itself as the spontaneous insight - the content of the 'Aha moment', or of the 'Eureka' experience. This kind of absence of focused balance in existing literature makes researchers working in the area of mathematical creativity to reflect about the absence of 'authoritative definition of creativity'. Together with that absence comes the 'looseness' of our culture of mathematical creativity, and this in itself might have

2 The idea of Gestalt has its roots in theories by Johann Wolfgang von Goethe and Ernst Mach. Max Wertheimer is to be credited as the founder of the movement of Gestalt psychology. The concept of Gestalt itself was first introduced in contemporary philosophy and psychology by Ehrenfels in his work Über Gestaltqualitäten (On the Qualities of Form, 1890). The central principle of gestalt psychological theory is that the mind forms a global whole with self-organizing tendencies. This principle maintains that the human mind considers objects in their entirety before, or in parallel with, perception of their individual parts; suggesting the whole is greater than the sum of its parts. negative impact upon nurturing creativity in mathematics classrooms, and beyond.

In fact, the investigation by Leikin (2009: 129143 ) indicates that the design of instruction and research based on the Torrance tests of Creative Thinking actually lowers the creativity. The authors point, we believe correctly, to the fluency and flexibility as the carriers of the habit which diminished the originality of student "when students become more fluent they have less chance to be original" This complementary relationship between fluency and flexibility on one hand and creativity on the other hand, determines attitudes when conducting the research into creativity based on definition, because such approach may result in undesired lowering of creativity while impacting negatively on culture of the field.

Culture of creativity in the field corresponds to the value we attach to the creativity itself. The absence of the 'authoritative approach or definition of creativity' in mathematics education reflects the ambiguities contained in the value of creativity as valued by mathematics educators. It is time then to look for such a definition of creativity in mathematics that places its understanding on firmer, unambiguous foundation.

\section{Bisociation}

The theory developed by Arthur Koestler in his 1964 work, Act of Creation, gives us such definition. It builds on our understanding of creativity on the basis of a thorough inquiry into the 'Aha moment' - a bisociative leap of insight, the very site of creativity according to Sriramana (2005). Arthur Koestler defines 'bisociation' as 'the spontaneous flash of insight, which...connects the previously unconnected frames of reference and makes us experience reality at several planes at once... " (Koestler, 1964: 45). Koestler clarifies the meaning of 'insight", by invoking Thorpe's 1956 definition of insight "an immediate perception of relations" (Koestler, 1964: 548). Koestler also refers to Koffka’s (Koffka, 1935) 
understanding of insight as the "interconnection based on properties of these things in themselves" (Koestler, 1964: 584). In the words of Koestler:

"The pattern... is, the perceiving into situation or Idea, $L$, in two self-consistent but habitually incompatible frames of reference, $M_{1}$ and $M_{2}$. The event $\mathrm{L}$, in which the two intersect, is made to vibrate simultaneously on two different wavelengths, as it were. While this unusual situation lasts, $\mathrm{L}$ is not merely linked to one associative context, but bisociated with two." (Koestler, 1964: 35)

Consequently, the creative leap or "an immediate perception of relations" can take place only if we are participating in at least two different frames of thinking, or matrices of discourse. The following quote, taken from Einstein's autobiographical notes (Schilpp, 1949:7) informs us how, in general, this "immediate perception of relations" takes place in the mind of the scientist, in agreement with Koestler's definition:

"What exactly is thinking? When at the reception of sense impressions, a memory picture emerges, this is not yet thinking, and when such pictures form series, each member of which calls for another, this too is not yet thinking. When however, a certain picture turns up in many of such series then - precisely through such a return - it becomes an ordering element for such a series, in that it connects series, which in themselves are unconnected, such an element becomes an instrument, a concept." (Koestler, 1964: 7)

\section{Cultural Values of Bisociation}

Bisociation has the power, together with the construction of the schema of a new concept through "the immediate perception of relations", to transform a habit into originality in agreement with the Koestler's battle cry "The act of creation is the act of liberation - it's the defeat of habit by originality!” (Koestler, 1964: 96). Thus bisociation plays a dual role, that of a cognitive reorganizer and that of an effective liberator from a habit - it's planting dou- ble roots for creativity. The confirmation of the role as the affective liberation can be glimpsed from the research of Liljedahl, (Liljedahl, 2009: 213) "Aha experience has a helpful and strongly transformative effect on a student's beliefs and attitudes towards mathematics.... The Unity of Cognitive Reorganization with Affective Liberation is the characteristic quality of the Act of Creation - one of the new central cultural values brought forth by the new definition of creativity in mathematics.

The second new central cultural value brought forth by bisociation is the emphasis on the Democratization of Creativity. The quest for the democratization of creativity is the response to the seeming preoccupation of educational profession with the creativity of gifted children. There are two recently published excellent collections of papers, dealing with creativity in mathematics education (Sriraman and Lee, 2011; Leikin et al., 2009). Both collections join the issue of creativity with the education of gifted students, implicitly indicating that the interest in creativity of all learners of mathematics is not the central focus of the field. There can be several reasons for such a restrictive focus on creativity: it could be due to the efforts of globalization ${ }^{3}$ so that "the winds are changing" (Sriraman and Lee, 2011: 2) or it could be that our understanding of the creative process is not sufficiently sharp to allow for the effective focus of research on the mathematical creativity by all students including, of course, the gifted. The proposed definition of creativity as the "spontaneous leap of insight," brings forward the "Aha moment', easily observable within a general population, as the basis on which to investigate the creativity of all students. Both, the investigation into creativity and its facilitation for all rest on two following observations.

3 In approximate terms, globalization implies the freedom of capital, which is attracted by high rate of profit. Translated into didactic of mathematics education, capital is interested in new profitable discoveries, what leads to interest in giftedness as condition which promises higher than standard achievements and related profits. 
1. Statement of Hadamard (Hadamard, 1945: 104): "Between the work of the student who tries to solve a problem in geometry or algebra and a work of invention, one can say that there is only the difference of degree, the difference of a level, both works being of similar nature".

2. Koestler "minor subjective bisociation processes....are the vehicle of untutored learning" (Koestler, 1964: 658).

Since minor subjective bisociations are the standard vehicle of self-learning experienced by everyone, and since their nature is similar to that of the mature mathematical inventor, we can therefore view bisociation as the process that underlies creativity in mathematics for all - this suggests its usefulness in defining creativity in general.

The method of facilitating creativity in the classroom is suggested by the essential component of its definition "...connects previously unconnected frames of reference and makes us experience reality on several planes at ones" (Koestler, 1964:45). It suggests organization of learning environment along the interface of at least two intuitively (or better, habitually) unconnected frameworks such as geometrical line and real numbers, simultaneous discussion of several different representations of fractions in the context of operations (Prabhu et al., 2014) or along elementary algebra/ESL interface (Czarnocha, 2014a). Working along such bisociative frameworks increases the probability of "leaps of insight" both by students and teachers (examples below).

Moreover, since according to Koestler "minor subjective bisociation processes are the vehicle of untutored learning" (Koestler, 1964: 658) we need to create classroom conditions which approximate conditions of untutored learning which is best obtained by the discovery (or inquiry leading to discovery). Hence, the nature of bisociation provides a theoretical justification for the discovery method developed to its natural completion by the Texas
Discovery method of R. L. Moore in US (Majavier, 1999). ${ }^{4}$

Below we provide three classroom examples of such pedagogy. The first one was constructed and implemented by Prabhu (Prabhu, 2014) in her classes of statistics and algebra. It used the notion of Koestler triptych and its aim was to consciously focus student attention on the interface between two related concepts to bring forth the "hidden analogy" between them.

\section{Bisociative Facilitation of Creativity}

\section{Design of Triptych - Based Assignments}

The Act of Creation (Koestler, 1964:45) defines bisociation, that is, "the creative leap [of insight], which connects previously unconnected frames of reference and makes us experience reality at several planes at once." Consequently, the creative leap of insight, or bisociation, can take place only if we are considering at least two different frames of reference or discourse.

How do we facilitate this process? Koestler offers a suggestion in the form of a triptych, which consists of "three panels...indicating three domains of creativity which shade into each other without sharp boundaries: Humour, Discovery and Art" (Koestler, 1964: 27).

4 Discovery method of teaching consists in creating learning environment which allows for student discovery of chosen mathematical concepts. Texan Discovery method generalizes that approach to full curriculum of graduate courses such as calculus, point set topology, euclidean and non-euclidean geometry e.t.c. A full course of Freshman calculus of the Texan discovery method might be a set of circa 150 axioms and theorems to prove, which leads the student to the discovery of all fundamental concepts of that subject. The level of student engagement parallel the engagement of participants in post graduate research seminars in European universities. 


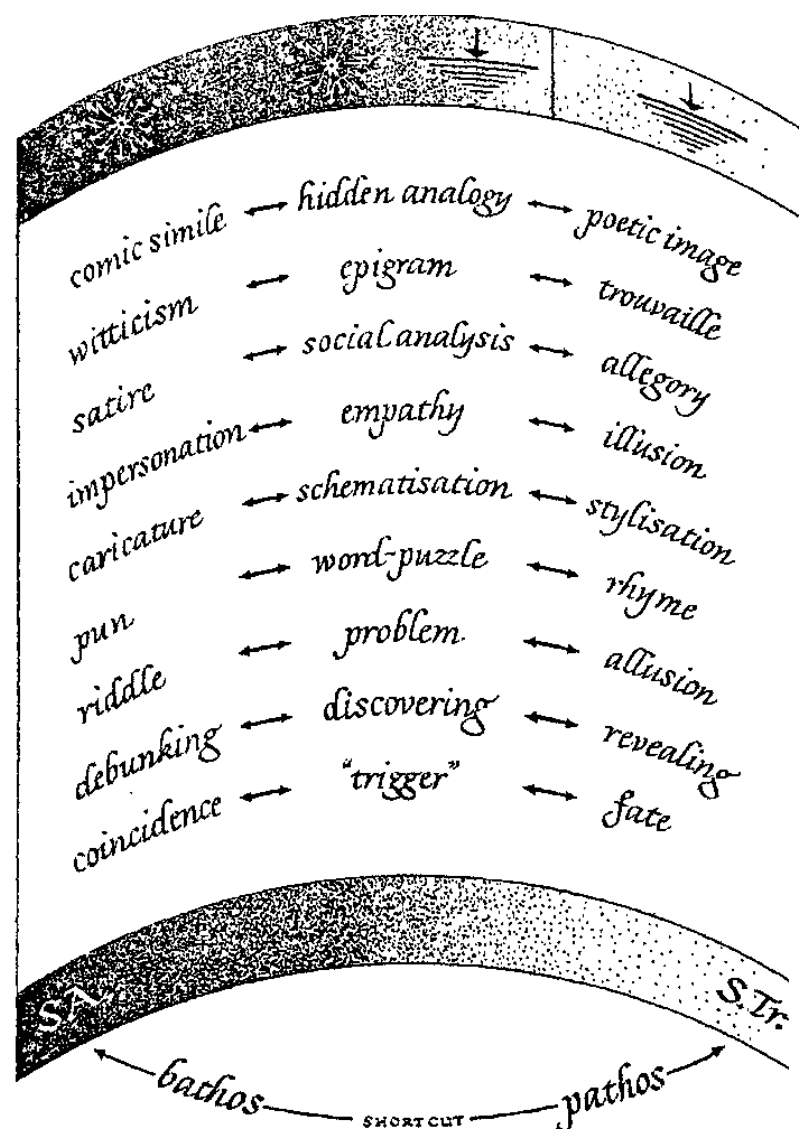

Figure 1. Koestler Triptych

Each such triptych stands for a pattern of creative activity, for instance:

Comic Comparison $\Leftrightarrow$ Objective Analogy $\Leftrightarrow$ Poetic Image

The first is intended to make us laugh, the second to make us understand, and the third to make us marvel. The creative process to be initiated in our developmental and introductory mathematics urgently needs to address the emotional climate of learners, and here is where the first panel of the triptych comes into play - humour. Having found humour and the bearings of the concept in question, the connections within it have to be explored further to "discover" the concept in detail, and, finally, to take the students' individual breakthroughs to a level where their discovery is sublimated ${ }^{5}$ to Art.

Here's an example of the triptych assignment used by V. Prabhu (Prabhu, 2014) in her Introductory Statistics class:

Trailblazer $\Leftrightarrow$ Outlier $\Leftrightarrow$ Originality

$\Leftrightarrow$ Sampling $\Leftrightarrow$

$\Leftrightarrow$ Probability $\Leftrightarrow$

$\Leftrightarrow$ Confidence Interval $\Leftrightarrow$

$\Leftrightarrow$ Law of Large Numbers $\Leftrightarrow$

Lurker/Lurking Variable $\Leftrightarrow$ Correlation $\Leftrightarrow$ Causation

The triptych below is an example of student work:

$$
\begin{aligned}
& \text { Trailblazer } \Leftrightarrow \text { OUTLIER } \Leftrightarrow \text { Original } \\
& \text { Random } \Leftrightarrow \text { SAMPLING } \Leftrightarrow \text { Gambling } \\
& \text { Chance } \Leftrightarrow \text { PROBABILITY } \Leftrightarrow \text { Lottery }
\end{aligned}
$$

Lurking Variable $\Leftrightarrow$ CORRELATION $\Leftrightarrow$ Causation Testing $\Leftrightarrow$ CONFIDENCE INTERVALS $\Leftrightarrow$ Results Sample Mean $\Leftrightarrow$ LAW OF LARGENUMBERS $\Leftrightarrow$ Probability

Triptych assignments facilitate student awareness of connections between relevant concepts and, thus, further support understanding. However, what maybe even more important is the accompanying discussions that help break the 'cannot do' habit and transform it into original creativity; below is the triptych completed by a student from a developmental algebra class:

$$
\begin{aligned}
\text { Number } & \Leftrightarrow \text { Ratio } \Leftrightarrow \text { Division } \\
\text { Part-Whole } & \Leftrightarrow \text { Fraction } \Leftrightarrow \text { Decimal } \\
\text { Particularity } & \Leftrightarrow \text { Abstraction } \Leftrightarrow \text { Generality } \\
\text { Number } & \Leftrightarrow \text { Variable } \Leftrightarrow \text { Function } \\
\text { Multiplication } & \Leftrightarrow \text { Exponent } \Leftrightarrow \text { Power }
\end{aligned}
$$

5 Sublime transformation of scientific discovery to art means its artistic refinement, which inspire admiration or awe. For example the conceptual art of the sixties and seventies was the sublimation of mathematical concepts of geometry, World Trade Centre towers built in the seventies represented, among others, sublimation of straight line. 
The use of triptychs brings back the game and puzzle-like aspects inherent in mathematics into the mathematics classroom. What is the connection between the stated concepts? What other concepts could be connected to the given concepts? Given the largely computational nature of the elementary classes, and the students' habit of remembering pieces of formulas from previous exposures to the subject, a forum for making sense and exploring meaning is created to help connect prior knowledge with new synthesized reasoned exploration. The question 'how', answered by the computations, is augmented with the 'why' through the use of mathematical triptychs (Prabhu, 2014).

The second example reports the presence of the 'Aha moment' during the discussion of the process of solving a linear equation between two classmates (Poland, $3^{\text {rd }}$ grade). Originally interpreted with the help of metonymy ${ }^{6}$, it is an example of bisociation between perceptual and logical frames of thinking.

\section{Perceptual-logical Resonance}

The investigations into perceptual-logical resonance have been carried on by the group of teacher-researcher around Roberto Tortora and Maria Mellone from Federico Segundo University in Naples (Iannece et al., 2005). The example of the resonance has been provided by Polish educators, Wacek Zawadowski and Celina Kadej (Kadej, 1999) and it has been organized on the principles of Theory of Resonance developed by the author (Czarnocha, 2014b; Prabhu and Czarnocha, 2014).

\section{An elephant - or what use can be made of metonymy?}

Linear equations with one unknown can be solved by students in the elementary school in Po-

\footnotetext{
6 Metonymy is a sudden change of meaning of the word or a symbol; here from "elephant" meaning itself to "elephant" meaning an unknown.
}

land. Those are simple equations and students often formulate them by themselves while solving word problems. Sometimes the problems lead to equations a bit more complex than the elementary additive equations of the type $x+a=b$.

I have had an opportunity to listen to the discussion of two enthusiastic students in third grade of the elementary school solving a standard word problem: The sum of two numbers is 76 . One of the numbers is 12 more than the other. Find both numbers. It was a problem from a Semadeni's set of problems for the $3^{\text {rd }}$ grade (Semadeni, 1987) and one had to solve it using equations and that's where the difficulty appeared:

Two pupils $\mathrm{P} \& \mathrm{~B}$ 's dialogue is given below. Pupil named P wrote the equation: $\mathrm{x}+(\mathrm{x}+12)=76$. To solve it was a bit of a problem for him, but still he dealt with it. He drew an interval and then a following dialog had taken place:

P: That is that number: he extended this interval by almost the same length, and the another one like that.
And this is that number plus 12
$\mathrm{B}$ : and this all together is equal to $76 \ldots$
$\mathrm{P}:$ No, this is an equation, d'you understand...
B: could not accept it...
B: Why did you draw this interval? You don't know yet what it's supposed to be?
P: That's not important.
B: Why 76 ?
P: 'cause that's what is in the problem
$\mathrm{B}$ : that $\mathrm{x}$, that $\mathrm{x}$ add 12 and that's supposed to be $76 . . ?$

$\mathrm{P}$ : Look instead of $\mathrm{x}$ there is a little square in the book (P showed the little square in the book). else.

$\mathrm{B}$ : Aha, but here, here is written something

P: But it could be as here. And now I am inputting a number into this square. 
B: A number?! Why into the square?

P: No, it's into the window. Into this window I input the number which comes out here.

$\mathrm{B}$ : But here is a square (B insisted).

P: It's not a square but a window, and one inputs the numbers into that window.

B: How so?

P: Two windows are equal 64, one window is equal 32. Well, now, you subtract 12 from both sides, and you see that the two windows are equal to 64 .

$\mathrm{B}$ : But are there numbers in the windows?

P: Two windows are 64 , so one window is 32

B: Window!?

P: That's right, a window. Look here: an elephant and an elephant is equal 64. Therefore what is one elephant equal to? Two elephants are equal 64. So, one elephant is equal to what?

B: An elephant? Hmm, I see. One elephant equals 32. I understand now... so now the equation...

P: If two elephants are equal 60, then one elephant is equal what?

B: An elephant?, ok, one elephant equals 30. I see it now...... Now equation.............aaaaaaa

Thinking about that dialog one can have several questions: Why an elephant in P's thinking? Why window didn't work for B neither did line interval but an elephant worked? Where did the elephant come from?

There were two statutes on the bookshelf, a piggy and an elephant. $\mathrm{P}$ chose the elephant, ready to be taken as a symbol of some mental object. An elephant was used as an adequate symbol of a mental object, which often is called an $\mathrm{x}$, but it doesn't have to.

It's a fascinating example of the 'Aha moment', where the bisociative framework is made up of the perceptual frame within which came the elephant, and of the logical frame of solving linear equations.
More examples of the process can be found in Baker (2014b).

\section{The domain of the function $\sqrt{X+3}$}

The following example is from the remedial class of intermediate mathematics. The domain of the function $\sqrt{X+3}$ is at the center of the dialog.

Consider the square root domain question in the classroom of a teacher researcher, demonstrating the interaction between student and instructor, in which the latter is able to get the student engaged in the thinking process and hence to facilitate student creativity.

Note that it is the spontaneous responses of the student from which the teacher-researcher creates/determines the next set of questions, thus balancing two frames of reference, his/her own mathematical knowledge and the direction taken by the student. Similarly the student has her own train of thought and prompted by the teacher-researcher's questions, she must now balance two frames of reference to determine her next response. The analysis of the dialog is conducted with the help of bisociation theory and Piaget and Garcia Triad in Baker (2014a). $\sqrt{X+3}$

The problem starts with the function $\mathrm{f}(\mathrm{x})=$

0 . The teacher asked the students during the review: "Can all real values of be used for the domain of the function $\sqrt{X+3}$ ?"

1. Student: "No, negative $X$ 's cannot be used." (The student habitually confuses the general rule which states that for the function $\sqrt{X}$ only positivevalued can be used as the domain of definition, with the particular application of this rule to $\sqrt{X+3}$.)

2. Teacher: "How about $X=-5$ ?"

3. Student: "No good."

4. Teacher: "How about $X=-4$ ?"

5. Student: "No good either." 
6. Teacher: "How about $X=-3$ ?"

7. Student, after a minute of thought: "It works here."

8. Teacher: "How about $X=-2$ ?"

9. Student: "It works here too."

A moment later

10. Student adds:" Those $X$ 's which are smaller than -3 can't be used here." (Elimination of the habit through original creative generalization.)

11. Teacher: "How about $\mathrm{g}(\mathrm{x})=\sqrt{X-1}$ ?"

12. Student, after a minute of thought: "Smaller than 1 can't be used."

13. Teacher: "In that case, how about $\mathrm{h}(\mathrm{x})=$ $\sqrt{X-a}$ ?"

14. Student: "Smaller than "a" can't be used."(Second creative generalization)

Koestler defines a matrix as, "any pattern of behaviour governed by a code of fixed rules," (Koestler, 1964: 38) and, in statement (1) above, the limitations of the students' internal matrix, or problem representation, are demonstrated. The teacher, adjusting to the students' limited matrix provides two examples (lines (6) and (8)) that provide a perturbation, or a catalyst, for cognitive conflict and change. Recall that, as Von Glasersfeld (1989: 127) writes, "...perturbation is one of the conditions that set the stage for cognitive change".

In lines (6)-(9) the student reflects upon the results of the solution activity. Through the comparison of the results (records) they abstract a pattern, Q 'the learners' mental comparisons of the records allows for recognition of patterns" (Simon et al., 2004). Thus, in this example the synthesis of the student's matrix for substitution and evaluation of algebraic expressions with their limited matrix of what constitutes an appropriate domain for radical functions (bisociation) resulted in the cognitive growth demonstrated in line (10).
In lines (11) and (12), the perturbation brought about by the teacher's questions, leads the student to enter the second stage of the Piaget \& Garcia's Triad. The student understood that the previously learned matrix or domain concept of radical functions, with proper modifications, extended to this example. They student was then able to reflect upon this pattern and abstract a general structural relationship in line (14), characteristic of the third stage of the Triad (Piaget \& Garcia, 1983).

We propose the method of scaffolding presented above as the teaching-research inspired guided discovery method of creating a bridge between Koestler's insistence on the "un-tutored' nature of bisociation with Vygotsky emphasis on the socially structured nature of learning environment.

\section{Bisociation and Simultaneity of Attention}

Bisociation theory helps us to clarify certain ambiguities present in the professional discussion of mathematics creativity. The discussion here is grounded in the important Koestler's distinction between two kinds of thinking, progress in understanding reached through bisociation and exercise of understanding reached through the explanation of the particular case, through examining or using the coda formed by past experiences, both of which are defined below. Progress in understanding obtained through bisociation requires a new structure of attention which hasn't been discerned before in the field of mathematics education: that is the simultaneous attention towards two different frames of thinking. Identification of the simultaneity of attention as underlying bisociation brings us closer to the discussions of simultaneity in physics, both in Relativity theory and in the foundations of Quantum Mechanics. One may conjecture that similarly to the recognition of the fundamental character of simultaneity in physics, further research will demonstrate the fundamental nature of simultaneity of attention in the process of learning. 
1. The standard division of creativity into absolute and relative ${ }^{7}$ is misleading because it seems to suggest an essential difference between the two. Similarly, in each intellectual domain the tools and the language through which creativity is expressed vary, but the process of insight through bisociation is exactly the same. (See Section Cultural Values of Bisociation)

2. Situating the definition of creativity in the illumination stage of the Wallas definition itself provides a new perspective upon questions raised in recent discussions on the subject. In particular, Sriraman et al., (2011: 121) assertion can be qualified:

...when a person decides or thinks about reforming a network of concepts to improve it even for pedagogical reasons though new mathematics is not produced, the person is engaged in a creative mathematical activity".

Whether the process described above is or is not a creative mathematical activity can be decided on the basis of Koestler's distinction between progress of understanding - the acquisition of new insights, and the exercise of understanding - the explanation of particular events (p.619). Progress in understanding is achieved by the formulation of new codes through the modification and integration of existing codes by methods of empirical induction, abstraction and discrimination, bisociation.

The exercise or application of understanding to the explanation of particular events then becomes an act of subsuming the particular event under the codes formed by past experience. To say that "we have understood a phenomenon means that we have recognized one or more of its relevant relational features as particular instances of more general or familiar relations, which have been previously abstracted and encoded" (Koestler, 1964: 619).

7 Absolute creativity has a value at large, e.g. creativity of Sheakspire or Einstein; the relative creativity has a subjective value for an individual.
If for example, I decide to design the developmental course of arithmetic/algebra based on my knowledge of the relationship between arithmetic and algebra (generalization and particularization), which involves the redesign of the curriculum, that is of 'the network of concepts', I am engaged in the exercise of understanding of mathematics, distinctly different from creative progress of understanding in mathematics. It may however, depending on the initial knowledge of the teacher, be a creative activity in pedagogical meta-mathematics, that is understanding mathematics from the teaching point of view the content of professional craft knowledge.

The bisociation theory, in which on the one hand, creativity is "an immediate perception of relation(s)", and on the other it is the affective catalyzer of the transformation of habit into originality, interacts well with MST methodology (Leikin, 2009). It predicts the absence of the difference between absolute and relative creativity observed by authors of the experiment. Moreover, the observed fall in the expression of originality reported by Leikin (2009), as well as the correlation between creativity and originality is natural in the context of the relationship between habit, creativity and originality - a point made explicit in the often quoted Koestler's assertion "Creativity is the Defeat of the Habit by Originality". The authors point correctly to the fluency and flexibility as the carriers of the habit which diminished the originality of student subjects "...when students become more fluent they have less chance to be original" (Leikin, 2009: 129143). This apparently complementary relationship between fluency and creativity dictates an utmost care in conducting the research into creativity with the help of the definition which includes fluency, because it may result in undesired lowering of creativity. And that we don't want, especially in the 'underserved communities. This observation brings in the old question to the fore: What is the optimal composition of fluency and creativity in the preparation of teachers of mathematics, as well as in classroom teaching? 
1. The same distinction between the progress in understanding and the exercise of understanding, helps us to clarify interpretation of an 'Aha moment' by recent presentation of Palatnik and Koichu (2014). The authors discuss the occurrence of the 'Aha moment' in the process of generalization of the numerical pattern obtained from calculating the maximal number of pieces that can be gotten from cutting a circle by straight lines as a function of the number of lines. There is an ambiguity in assigning the timing of the 'Aha moment', which we want to address from the bisociative point of view. We quote an extensive excerpt of their discussion:

2. Ron took the lead. In his words: "I was stuck in one to six. And I just thought...six divided by two gives three. I just thought there's three here, but I could not find the exact connection [to 22]. I do not know why, but I multiplied it by seven, and voila - I got the result."

3. One of these [Ron's] attempts began from computations $6: 3=2$ and $3 \times 7=21$. Ron realized that in the second computation is not just a factor that turns 3 into 21, but also a number following 6 in the vertical pattern. He noticed (not exactly in these words) the following regularity: when a number from the left column is divided by 2 and the result of division is multiplied by the number following the initial number, the result differs from the number in the right column by one. He observed this regularity when trying to convert 6 into 22, and almost immediately saw that the procedure works also for converting 4 into 11 and 5 into 16. He observed that even when division by 2 returns a fractional result $(5: 2=2.5)$, the entire procedure still works. The aha-experience occurred at this moment.
4. The bisociation theory suggests that the Aha moment took place a bit earlier, namely exactly at the moment when Ron observed the bisociative framework contained in the realization that 7 in the second computation is not just a factor that turns 3 into 21, but also a number following 6 in the vertical pattern. That was the spontaneous leap of insight, the progress in understanding of the problem by connecting two different frames - two different numerical patterns. The following computations quoted by the authors were already the result of the exercise of understanding reached in this Aha moment. We point out that partial responsibility for the absence of focus on that step as the fundamental one by the authors is borne by the Mason's theory of shifts of attention (Mason, 2008), which doesn't discern explicitly the simultaneity structure of attention needed for the bisociative leap of insight.

The introduction of the structure of simultaneity of attention raises some new research questions such as: What is the possible scope of simultaneous attention both in content and in time? One could also ask whether the scope of simultaneous attention is the same as the scope of the attention focused on a single object. If it is not the same, what is the dynamics through which attention focused on single objects transforms into the simultaneous attention upon both of them at once?

\section{Measurement of Creativity}

One of the chief reasons for the recent interest in Thorrace definition of creativity is its quantitative nature, which is therefore easily measurable. Fluency is measured by "the total number of interpretable, meaningful and relevant ideas generated in response to the stimulus"; while flexibility has been evaluated by "the number of non-repeating solutions" in stu- 
dents solution spaces. However, both, Koestler's theory of bisociation as well as the empirical results obtained by co-workers of Leikin (2009), Anat LevavWaynberg and Raisa Guberman suggest that, the increase of flexibility and fluency, diminishes originality, and consequently creativity. Taking into account that, accordingly to Koestler Creativity is "the defeat of habit by originality", it follows that the development of habits to increase the number of solutions works against creativity itself. It follows that Torrace definition does not measure creativity, but the composition of creativity with the habit, conflating the measurement of creativity itself former.

Piaget-based APOS (Arnon et al, 2014: 66) theory of the conceptual mathematical development as explained by Baker (2014b) in which he had coordinated Koestler's bisociation theory with APOS theory, found out that interiorization and encapsulation, two basic reflective abstractions of APOS admit a bisociative framework. This implies that both of them can be realized through an 'Aha moment', a spontaneous leap of insight. Consequently the measurement of the creativity involved in the Aha moment could be the degree to which the particular reflective abstraction contributes to the development of the concept in question. We will obtain this way an answer to the question - How much did creativity of the 'Aha moment' contributed to learner's conceptual development?, and therefore to the progress of mathematical understanding.

\section{Teaching-Research - the bisociative framework for teaching}

The search for bisociative frameworks that is for two different, habitually incompatible (in Koestler's words) matrices of experience, using Koestler's description, leads are directly to the teaching-research methodology which underlie this paper. The original discovery of bisociation by Prabhu (2014) has taken place in the context of the teaching experiment Problem Solving in Remedial Mathematics: Jumpstart to Reform conducted in 2010/2011 with the help of Teaching-Research/NYCity Model (Czarnocha, 2014c). Teaching-Research NYCity (TR/NYCity) Model is a methodology for classroom investigation of students' learning processes conducted simultaneously with teaching by the classroom instructor, the aim of which is a real-time improvement of learning in the very same classroom, and beyond. Since, as a domain, teaching is not habitually related to the domain of research, a teacherresearcher who is attempting to do both, acts within a bisociative framework, which is responsible for the large dose of creativity generated by that activity. Hence we see here bisociation as the single concept/process which can underlie both student's and teacher' creativity.

A full collection of examples and new creativity-based results obtained through the TR/NYCity Model is contained in the book The Creative Enterprise of Mathematics Teaching-Research: Elements of Methodology and Practice - from Teachers to Teachers to be published by Sense Publisher in 2015.

\section{Conclusion}

The presented discussion has proposed the new definition of creativity in mathematics based on the Koestler's theory of bisociation. We have analyzed the current, often used definitions of creativity utilized in mathematics education, and showed their limits as well possible negative effects on the development of creativity by students of mathematics. The discussion has led us through the characterization of relevant features of bisociation pointing out to the new cultural values of the unity between the cognitive and affective aspects of learning brought forth by the new definition. We have given limited examples of bisociation to the discussion of its classroom facilitation; many examples of bisociative thinking in humor, science and art are included in Koestler's Act of Creation. The analysis of the description of the particular 'Aha moment' by Palatnik and Koichu (Palatnik and Koichu 2014) sug- 
gested the importance to discern and to recognize simultaneity of structure of attention, which underlies simultaneity within the process of bisociation. Formulation of that structure opens many new research questions. The new qualitative measurement of creativity with the help of APOS theory has been proposed in the final pages of the essay but this still awaits the empirical verification. ${ }^{8}$ Finally, the teaching research methodology with the help of which the presented results have been obtained was shortly presented as the creative bisociative framework for teaching. The concern for the coherence of the presentation motivated us to leave some important issues outside such as bisociation as the basis of new computer creativity domain (Berthold, 2012) and the relationship of mathematics with poetry as the bisociative framework.

\section{References}

- Arnon, I., Cottrill, J., Dubinsky, E., Oktac, A., Fuentes, S.R., Trigueros, M. and Weller, K. (2014). APOS Theory. A Framework for Research and Curriculum Development in Mathematics Education. Springer.

- Baker, W. (2014a). Reflection upon Solution Activity in a Teaching-Research Classroom: Bisociation and Reflective Abstraction. In: Czarnocha, B., Baker, W., Dias, O., Prabhu, V. and Flek, R. (ed.) The Creative Enterprise of Mathematics Teaching-Research (229-262). Rotterdam/Taipei: Sense Publishers. (2014, to be published)

- Baker, W. (2014b). Koestler's Theory as a Foundation for a Classroom Problem-Solving Environment. In: Czarnocha, B., Baker, W., Dias, O., Prabhu, V. and Flek, R. (ed.) The Creative Enterprise of Mathematics Teaching-Research (37-54). Rotterdam/Taipei: Sense Publishers. (2014, to be published)

- Berthold, M.R. (2012). Bisociative Knowledge Discovery. Springer.

- Czarnocha, B. (2014a). The Flow of Thought across the Zone of Proximal Development between Elementary Algebra and Intermediate English as a Second Language. In: Czarnocha, B., Baker, W., Dias, O., Prabhu, V. and Flek, R. (ed.) The Creative Enterprise of Mathematics Teaching-Research (313-330). Rotterdam/Taipei: Sense Publishers. (2014, to be published)

- Czarnocha, B. (2014b). Bisociation of Arthur Koestler in the "Act of Creation" (1964) as the theory of the Aha! moment-the Basis for Mathematical Creativity in the Classroom and Beyond Presentation, University Federico Segundo, Napoli, Italy, May 9, 2014. (ppt presentation).

- Czarnocha, B (2014c). Teaching-Research/New York City Model (TR/NYCity). In: Czarnocha, B., Baker, W., Dias, O., Prabhu, V. and Flek, R. (ed.) The Creative Enterprise of Mathematics Teaching-Research (3-16). Rotterdam/Taipei: Sense Publishers. (2014, to be published)

- Ehrenfels, von C. (1890). Über Gestaltqualitäten [On the Qualities of Form]. Vierteljahrsschrift für wissenschaftliche Philosophie, 14, 249-292.

- Hadamard, J. (1945). The Psychology of Invention in the Mathematical Field. Princeton University Press.

- Kadej, C. (1999). An elephant - or what use can be made of metonymy? Matematyka \#2, Poland.

- Kattou, M., Kontoyianni, K., Pitta-Pantazi, D. and Christou, C. (2011). Does Mathematical Creativity Differentiate Mathematical Ability? Proceedings of the Seventh Congress of the European Society for Research in Mathematics Education 7 (CERME 7) (1056-1065). Rzeszow, Poland.

8 The teaching experiments for the empirical verification are scheduled for 2015/2016. 
- Koestler, A. (1964). The Act of Creation. London: Hutchinson \& Co, LTD.

- Koffka, K. (1935). Principles of Gestalt Psychology. New York: Hartcourt Brace.

- Leikin, R., Berman, A., Koichu, B. (ed.) (2009). Creativity in Mathematics Education of Gifted Students. Sense Publishers.

- Leikin, R. (2009). Exploring mathematical creativity Using Multliple Solution Tasks. In: Leikin, R., Berman, A. and Koichu, B. (ed.) Creativity in Mathematics Education of Gifted Students (129-145). Sense Publishers.

- Liljedahl, P. (2009). In the Words of the Creators. In: Leikin, R., Berman, A. and Koichu, B. (ed.) Creativity in Mathematics Education of Gifted Students (51-70). Sense Publishers.

- Mann, E. (2005). Mathematical Creativity and School Mathematics: Indicators of Mathematical Creativity in Middle School Students (Doctoral dissertation).

- Mahavier, W.S. (1999). What Is The Moore Method? Primus, 9, 339-254.

- Mason, J. (2008). Being Mathematical With and in front of Learners: Attention, Awareness, and Attitude as sources of differences between Teacher Educators, Teachers \& Learners. In: Jaworski, B. and Woods, T. (ed.) The Mathematics Teacher Educator as a Developing Professional (31-86), Rotterdam/Taipei: Sense Publishers.

- Palatnik, A. and Koichu, B. (2014). Reconstruction of One Mathematical Invention in Liljedahl,P., Oesterly, S., Nicol, C. \& Allan, D. Proceedings of the Joint Meeting of PME 38 and PME-NA 36 (Vol. 4, 377-384).

- Prabhu, V. (2014). The Creative Learning Environment. In: Czarnocha, B., Baker, W., Dias, O., Prabhu, V. and Flek, R. (ed.) The Creative Enterprise of Mathematics Teaching-Research (17-36). Rotterdam/Taipei: Sense Publishers. (2014, to be published)

- Prabhu, V., Barbatis, P. and Pflanzer, H. (2014). The Poznan Theatre Problem: the Role of Problem-Posing and Problem-Solving in Stimulating Self-Guided Discovery in Developmental Mathematics Classes. In: Czarnocha, B., Baker, W., Dias, O., Prabhu, V., Flek, R. (ed.) The Creative Enterprise of Mathematics TeachingResearch (303-312). Rotterdam/Taipei: Sense Publishers. (2014, to be published)

- Prabhu, V. and Czarnocha, B. (2014). Democratizing Mathematical Creativity through Koestler Bisociation Theory. In: Liljedahl,P., Oesterly, S., Nicol, C. \& Allan, D. (ed.) Proceedings of the Joint Meeting of PME 38 and PME-NA 36 (Vol. 5, 1-8).

- Semadeni, Z. (1987). Verbal Problems in Arithmetic Teaching. In: Proceedings of the International Congress of Mathematicians Berkeley, California, USA, 1986 (1697- 1706). International Congress of Mathematicians 1986.

- Silver, E. A. (1997). Fostering creativity though instruction rich mathematical problem solving and problem posing. International Reviews on Mathematical Education, 29 (3),75-80.

- Sriraman, B (2005). Are Giftedness and Creativity Synonyms in Mathematics? The Journal of Secondary Gifted Education. 17 (1), 20-36.

- Sriraman, B., Yaftian, N. and Lee, K.H. (2011). Mathematical Creativity and Mathematics Education: A Derivative of Existing Research. In: Sriraman, B. and Lee, K.H. (ed.) The Elements of Creativity and Giftedness in Mathematics (119-130). Sense Publishers.

- Schilpp, P. A. (1949). Albert Einstein. Philosopher Scientist. The Library of Living Philosophers. Open Court.

- Thorpe, W.H. (1956). Learning and Instinct in Animals. London: Methuen.

- Torrance, E. P. (1974). Torrance tests of creative thinking. Bensenville, IL: Scholastic Testing Service. 
- Iannece D., Mellone M., Tortora R. (2006). New insights into learning processes from some neuroscience issues. In: Proceedings of the 30th Conference of the International Group for the Psychology of Mathematics Education (Vol. 3, 321-328). Prague: Charles University.

- Wallas, G. (1926). The Art of Thought. New York: Harcourt Brace.

\section{др Бронислав Чарноха}

Хостос комјунити колеџ, Департман за математику, Универзитет града Њујорка, Сједињене Америчке Државе

\section{О култури креативности у математичком образовању}

Култура креативности у математичком образовању заснована је на дефиницијама креативности које се наводе у нашем истраживању и настојањима да се она спроведе у учионици. Међутим, не постоји јединствена дефиниција креативности у математичком образовању (Mann, 2006; Sriraman, 2005; Leikin, 2011, Kattou et al., 2011) која наставнику практичару ствара тачку ослонца у поучавању. Стога, култура креативности у математичком образовању не стоји на чврстим основама. Она сажима, између осталог, истраживање о креативности и истраживање о даровитости. Штавише, истраживања која је спровела група Леикинове (Leikin, 2009) открила су да нагласак на флуентности у размери креативног размишљања заправо умањује оригиналност, самим тим и креативност, што се слаже са Кестлеровим схватањем да је „креативност пораз навике од стране оригиналности“ (Koestler, 1964: 96). Из тих разлога су Прабуова и Чарноча научно полемисали на 38. међународној конференцији за психологију математичког образовања око прихватања бисоцијације Кестлеровог „Акта креације“, који је спонтани скок у унутрашњост као ауторитативна дефиниција креативности (Prabhu and Czarnocha, 2014). Овај рад представља теорију бисоцијације „аха“ момента, која се усредсређује на могућност елиминације инхибирајућих навика ума. Она истражује културне вредности које је донела нова дефиниција креативности, као што је демократизација, јединство креативности и мотивације у учењу уз подједнаку пажњу. Представљени су примери и методе примене у учионици. Разлика између бисоцијативног и асоцијативног учења наглашава увод у подједнаку пажњу као нову структуру пажње (Mason, 2008). Бисоцијација доноси са собом нове културне вредности: демократизацију истраживања и примену креативности, као и когнитивно-афективно јединство. Демократизација креативности заснива се на две поставке - Хадамарда и Кестлера. Хадамард изјављује (Hadamard, 1945: 104): „Између рада ученика који покушава да реши геометријски или алгебарски проблем и рада на проналаску, може се рећи да постоји разлика у степену, разлика у нивоу, а да су оба рада сличне природе“. Са друге стране, Кестлер (Koestler, 1964: 658) наводи: „Минорни субјективни бисоцијативни процеси [...] покретачи су учења које није вођено“. Пошто су минорне субјективне бисоцијације стандардни покретачи самоучења кроз које свако пролази и пошто је њихова природа слична оној коју има зрео математички изумитељ, можемо да гледамо на бисоцијацију као на процес који потпомаже креативност у математици за све. Бисоцијација је веома моћна идеја. Има моћ да заједно са конструкцијом схеме за нови појам „кроз непосредну перцепцију односа“ трансформише навику у оригиналност, што је повезано са Кестлеровим вапајем за борбу (Koestler, 1964: 96): „Чин креације је чин ослобођења - она 
је пораз навике од стране оригиналности!“. Стога, бисоцијација игра двоструку улогу, ону која припада когнитивном реорганизатору и ону која припада ефикасном ослободиоцу од навике - то је усађивање дуплих корена за креативност. У истраживању Лилједала потврђена је улога коју може да наслути афективно ослобађање (Liljedahl, 2009: 213): „'Аха' искуство има помоћни и прилично трансформишући ефекат на веровања и схватања ученика према математици...“ Јединство когнитивне реорганизације и афективног ослобађања је карактеристичан квалитет за чин креације - једна од нових централних културних вредности коју доноси нова дефиниција креативности у математици. Представљање бисоцијације као централног појма за разумевање креативности допушта нам да квалификујемо одређене погледе у професионалном математичком образовању. Нарочито могу да се квалификују изјаве Срирамана (Sriraman et al., 2011: 121): „[...] Када особа одлучује или размишља о промени мреже појмова да би се она побољшала, па и из педагошких разлога, иако се нове математичке идеје нису формирале, особа је укључена у креативну математичку активност.“ Да ли процес, горе описан, јесте или није креативна математичка активност, може да се одреди на основу Кестлерове дистинкције између процеса разумевања - стицање нових сазнања - и вежбање разумевања - објашњење посебних случаја (Koestler, 1964). Напредовање у разумевању се постиже формулацијом нових кодова кроз модификацију и интеграцију постојећих кодова методима у емпиријској индукцији, апстракцији и способности разликовања, бисоцијацији. Вежба примене разумевања објашњења посебних догађаја постаје чин подсумирања посебних догађаја, а реализује се (у) кодовима које је формирало претходно искуство. Ако, на пример, одлучим да осмислим развојни програм аритметике/алгебре заснован на мом знању односа између аритметике и алгебре (генерализација и специјализација), ја сам укључен у вежбу разумевања математике, што се посебно разликује од креативног прогреса разумевања. Развојни програм укључује како редизајнирање курикулума, тако и редизајнирање „мреже појмова“. Прогрес разумевања који се стиче кроз бисоцијацију захтева нову структуру пажње која није постојала у претходном пољу математичког образовања, а то је симултана пажња према два оквира размишљања. Идентификација симултаности пажње као потпора бисоцијацији ближе нас доводи до симултаних дискусија о физици заједно са њеним гранама и у теорији релативитета и у основама квантне механике.

Клучне речи: креативност, бисоцијација, “аха“" моменат, симултаност пажње. 